\title{
Pemanfaatan Limbah Kulit Buah Pinang (Areca chatecu L.) Sebagai Biosorben Untuk Mengolah Logam Berat Pb (II)
}

\author{
Lisa Utami, Lazulva \\ Program Studi pendidikan Kimia Fakultas Tarbiyah dan Keguruan \\ Universitas Islam Negeri Sultan Syarif Kasim Riau \\ email: 1154_lazoelva@yahoo.com
}

\begin{abstract}
This research aims to investigate the utilization of the waste of Pinang Fruit peel as a biosorbent which function to process $\mathrm{Pb}$ (II) from contaminated water. The result showed that the absorbtion ability of $\mathrm{Pb}$ (II) was strongly influenced by the acidity of solution, contact duration and the initial concentration of the Pb (II) solution. The maximum absorbtion was 92,50\% at $\mathrm{pH}$ 6, initial concentration of 50 ppm in 75 minutes contact time. FTIR spectral data indicated the presence of amina, alcohol and carbonil groups. Isotherm Langmuir was at the maximum absorbtion of $0,877 \mathrm{mg} / \mathrm{g}$.
\end{abstract}

Keywords: absorption,biosorbent, isotherm Langmuir, Pinang Fruit Peel, Pb(II)

\section{PENDAHULUAN}

Dewasa ini, pencemaran air menjadi masalah yang sangat serius. Salah satu penyebab pencemaran air tersebut adalah logam berat, seperti logam $\mathrm{Pb}, \mathrm{Cd}, \mathrm{Cu}, \mathrm{Cr}, \mathrm{Hg}$ dan $\mathrm{As}$. Keberadaan logam-logam ini sangat berbahaya, meskipun dalam jumlah yang kecil. Logamlogam ini berasal dari aktivitas industri seperti penambangan logam, pelapisan dan pencampuran logam, industri penyamakan kulit, cat, pewarnaan, baterai, keramik dan produksi senjata. Karena sifatnya racun dan sulit terurai, logam ini dapat terakumulasi dalam rantai makanan, dan dapat menimbulkan gangguan terhadap lingkungan dan mahluk hidup (Khoiriah, et.al., 2015). Oleh karena itu pengolahan dan penghilangan logam berat dari lingkungan sangatlah diperlukan.

Salah satu teknik alternatif yang banyak dikembangkan untuk memisahkan ion-ion logam berat dari limbah cair adalah dengan memanfaatkan kemampuan beberapa biomaterial tumbuhan seperti kulit kacang polong, kulit jeruk, bubuk tempurung kelapa dan dedak padi sebagai adsorben ion-ion logam berat dan radionukleotida terlarut dari limbah cair (Mawardi, et.al., 2014). Proses ini kemudian disebut sebagai biosorpsi.

Biosorpsi menunjukkan kemampuan biomassa untuk mengikat logam berat dari dalam larutan secara metabolism-independent, pada sel hidup dan mati, yang melibatkan interaksi ionik, polar, interaksi gabungan dan mineralisasi antara ion logam dengan biopolimer (makromolekul) pembentuk sel, diantaranya protein dan polisakarida, fosfonan, chitin dan chitosan sebagai sumber gugus fungsi. Proses biosorpsi terutama terjadi pada permukaan dinding sel melalui mekanisme kimia dan fisika, seperti pertukaran ion, pembentukan kompleks dan adsorpsi yang melibatkan gugus fungsi dari makromolekul penyusun sel seperti gugus karboksilat, amina, tiolat, hidroksida, imidazol, sulfuhidril, fosfodiester dan gugus fosfat yang dapat berinteraksi dengan ion logam, sehingga proses biosorpsi diduga 
dipengaruhi oleh variabel-variabel seperti $\mathrm{pH}$ awal larutan, ukuran partikel biosorben, kecepatan pengadukan, waktu kontak dan kosentrasi awal larutan logam. Langmuir menggambarkan bahwa pada permukaan adsorben terdapat sejumlah tertentu pusat aktif (active site) yang sebanding dengan luas adsorben. Pada setiap sisi aktif hanya satu molekul atau satu ion yang dapat diserap. Penyerapan secara kimia, terjadi apabila terbentuk ikatan kimia antara zat terserap dengan sisi aktif adsorben, membentuk lapisan tunggal pada permukaan adsorben (monolayer adsorption) (Mawardi, et.al., 2014).

Berbagai alternatif bahan-bahan biologis dapat digunakan sebagai bahan baku biosorben. Bahan-bahan ini diantaranya alga, fungi dan bakteri. Namun penggunaan mikroorganisme tersebut memiliki beberapa kendala diantaranya adalah sangat dipengaruhi oleh kontaminan lain serta adanya kebutuhan perawatan seperti pemberian nutrisi tambahan (Kurniasari, Riwayati \& Suwardiyono, 2012). Alternatif bahan biologis lain yang dapat digunakan sebagai bahan baku biosorben adalah limbah produk-produk pertanian. Limbah produk pertanian merupakan limbah organik yang tentunya akan sangat mudah ditemukan dalam jumlah besar. Pemanfaatan dan penggunaan limbah pertanian sebagai bahan baku biosorben selain dapat membantu mengurangi volume limbah juga dapat memberdayakan limbah menjadi suatu produk yang mempunyai nilai jual. Oleh karena itu, potensi limbah pertanian cukup besar untuk digunakan sebagai bahan baku biosorben logam berat.

Pinang merupakan salah satu sektor pertanian di daerah Tembilahan kabupaten Indragiri Hilir Riau dengan luas daerah yang ditanami pinang 15.413 Ha. Pinang ditanam untuk dimanfaatkan biji dan batangnya. Saat ini biji pinang telah menjadi komoditi perdagangan, biji pinang saat ini diekspor dari Indonesia ke beberapa negara di Asia seperti India, Pakistan dan Nepal. Namun, kulit buah pinang saat ini belum dimanfaatkan secara optimal, selama ini kulit buah pinang hanya dibuang oleh petani.

Penelitian ini bertujuan untuk mengetahui pengaruh $\mathrm{pH}$, waktu kontak dan konsentrasi buah pinang sebagai biosorben ion logam $\mathrm{Pb}(\mathrm{II})$.

\section{METODE PENELITIAN}

\section{Alat}

Alat yang digunakan dalam penelitian ini adalah $\mathrm{pH}$ meter, FTIR dan AAS sedangkan bahan- bahan yang digunakan dalam penelitian ini adalah $\mathrm{Pb}\left(\mathrm{NO}_{3}\right)_{2}, \mathrm{Cd}\left(\mathrm{NO}_{3}\right)_{2}, \mathrm{NaOH}$, $\mathrm{HNO}_{3}$ dan aquades.

\section{Bahan}

Bahan- bahan yang digunakan dalam penelitian ini adalah $\mathrm{Pb}\left(\mathrm{NO}_{3}\right)_{2}, \mathrm{Cd}\left(\mathrm{NO}_{3}\right)_{2}, \mathrm{NaOH}$, $\mathrm{HNO}_{3}$ dan aquades

\section{Prosedur Kerja}

Kulit buah pinang sebagai biosorben didapatkan dari daerah Tambilahan kabupaten Indragiri Hilir Riau. Kulit buah pinang yang diperoleh kemudian dicuci dan dibilas dengan aquades bebas ion, setelah bersih kemudian dikeringkan di udara terbuka (tanpa terkena cahaya matahari langsung). Kulit buah pinang yang telah kering direndam dengan larutan 
asam nitrat $0,1 \mathrm{M}$ selama satu jam kemudian dicuci dan dibilas dengan aquades sampai air hasil pencucian kembali netral, kemudian keringkan kembali dengan cara yang sama, kemudian sampel dihaluskan sampai berukuran $150 \mu \mathrm{m}$ kemudian disimpan dalam desikator dan siap digunakan sebagai biosorben (Maward, et.al., 2014). Analisis gugus fungsional dalam kulit buah pinang dilakukan dengan FTIR sedangkan kemampuan biosorpsi kulit buah pinang dilihat dari variabel nilai $\mathrm{pH}$, konsentrasi dan waktu kontak yang dianalisa menggunakan AAS.

\section{Variabel Nilai pH Terhadap Penyerapan Ion Logam Pb}

Sebanyak $0,1 \mathrm{~g}$ kulit buah pinang yang telah dihaluskan ditambahkan ke dalam $25 \mathrm{~mL}$ larutan ion logam $\mathrm{Pb}$ dengan kosentrasi $20 \mathrm{mg} / \mathrm{L}$ dengan variasi $\mathrm{pH}$ 2,3,4,5 dan 6 dalam tabung erlemeyer $100 \mathrm{~mL}$ (Khoiriah et al., 2015). $\mathrm{pH}$ diatur dengan menggunakan $\mathrm{HNO}_{3}$ $0,05 \mathrm{M}$ atau $\mathrm{NaOH}$ 0,05 M, kemudian dilakukan pengocokan selama 60 menit dengan kecepatan 100 rpm (Yussof, et.al., 2014). Larutan di dekantasi kemudian disaring dengan kertas saring. Setiap percobaan dilakukan 2x pengulangan.

\section{Variabel Kosentrasi}

Sebanyak 0,1 g kulit buah pinang yang telah dihaluskan ditambahkan ke dalam $25 \mathrm{~mL}$ larutan ion logam $\mathrm{Pb}$ dengan variasi kosentrasi 10; 20; 30; 40 dan $50 \mathrm{mg} / \mathrm{L}$ dengan $\mathrm{pH}$ diatur 5 dalam tabung erlemeyer $100 \mathrm{~mL}$ (Khoiriah et al., 2015). pH diatur dengan menggunakan $\mathrm{HNO}_{3} 0,05 \mathrm{M}$ atau $\mathrm{NaOH} 0,05 \mathrm{M}$, kemudian dilakukan pengocokan selama 60 menit dengan kecepatan $100 \mathrm{rpm}$ (Yussof, et.al., 2014). Larutan di dekantasi kemudian disaring dengan kertas saring. Setiap percobaan dilakukan 2x pengulangan.

\section{Variabel Waktu Kontak}

Sebanyak 0,1 g kulit buah pinang yang telah dihaluskan ditambahkan ke dalam $25 \mathrm{~mL}$ larutan ion logam dengan variasi kosentrasi $20 \mathrm{mg} / \mathrm{L}$ dengan $\mathrm{pH}$ diatur 5 dalam tabung erlemeyer $100 \mathrm{~mL}$ (Khoiriah et al., 2015). $\mathrm{pH}$ diatur dengan menggunakan $\mathrm{HNO}_{3} 0,05 \mathrm{M}$ atau $\mathrm{NaOH}$ 0,05 M, kemudian dilakukan pengocokan dengan variasi waktu15; 30; 45; 60 dan 75 menit dengan kecepatan 100 rpm (Yussof, et.al., 2014) . Larutan di dekantasi kemudian disaring dengan kertas saring. Setiap percobaan dilakukan 2x pengulangan.

\section{HASIL DAN PEMBAHASAN}

\section{Analisis FTIR}

Sampel kulit buah pinang yang sudah dikeringkan dan dihaluskan hingga berukuran 150 $\mu \mathrm{m}$ dikarakterisasi menggunakan Fourier Transform Infrared (FTIR), menggunakan metoda pil KBr. Sampel diidentifikasi pada interval bilangan gelombang $400-4000 \mathrm{~cm}^{-1}$. Analisis FTIR bertujuan untuk mengetahui gugus fungsi yang terdapat di dalam biosorben (kulit buah pinang). Selanjutnya, hal ini akan memberikan informasi mengenai mekanisme ikatan dan gugus fungsi yang mungkin terlibat berinteraksi dengan ion logam. Analisis FTIR ini 
dilakukan dengan melihat adanya perubahan dari spektrum IR sebelum dan sesudah biosorpsi ion logam $\mathrm{Pb}^{2+}$ oleh kulit buah pinang.

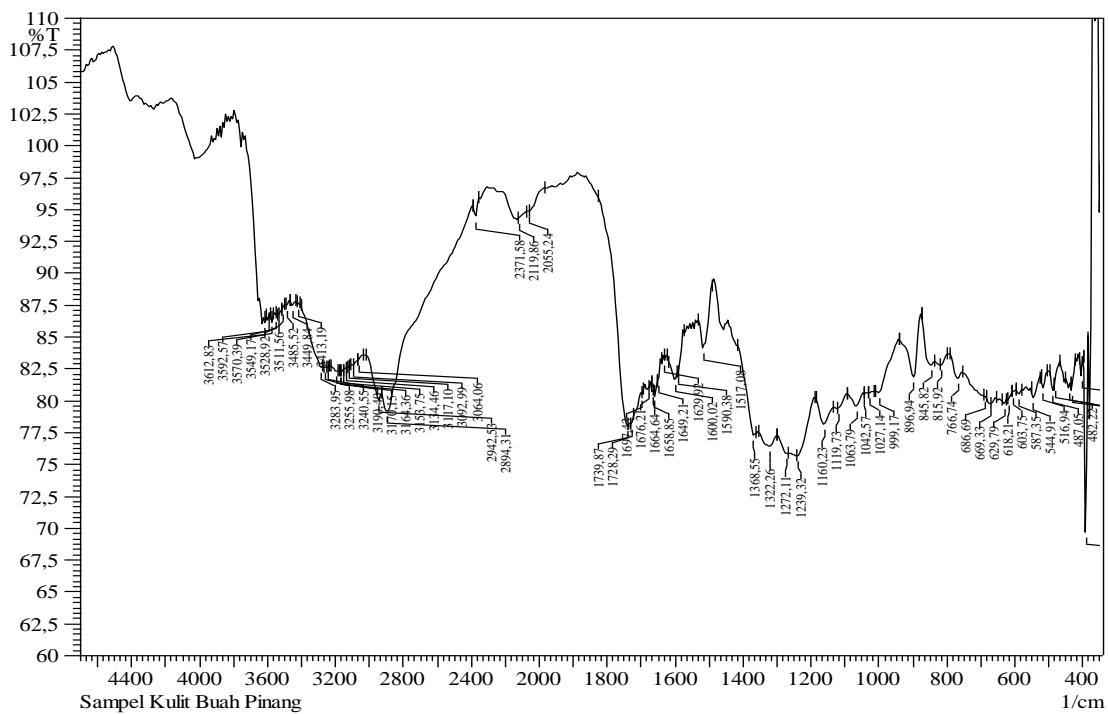

Gambar 1. Spektrum FTIR dari kulit buah pinang sebelum biosorpsi dengan ion logam

Gambar 1 menunjukkan spektrum FTIR dari sampel kulit buah pinang sebelum biosorpsi dengan ion logam $\mathrm{Pb}^{2+}$. Gambar 4.1 menunjukkan puncak yang lebar dan kuat yang teramati pada $3240,55 \mathrm{~cm}^{-1}$ dan $3612,83 \mathrm{~cm}^{-1}$ yang menunjukkan gugus fungsi $\mathrm{OH}$ dari alkohol sedangkan pita serapan pada daerah $3511,56 \mathrm{~cm}^{-1} ; 3528,92 \mathrm{~cm}^{-1}$ dan $3549,17 \mathrm{~cm}^{-1}$ menunjukkan gugus fungsi O-H dari asam karboksilat.

Pita serapan pada $686,69 \mathrm{~cm}^{-1}$ menunjukkan gugus $\mathrm{C}-\mathrm{H}$ cis-substitusi alkena dan pita serapan pada $815,92 \mathrm{~cm}^{-1}$ menunjukkan gugus $\mathrm{C}-\mathrm{H}$ tri-substitusi alkena serta pita serapan pada $766,74 \mathrm{~cm}^{-1}$ menunjukkan gugus $\mathrm{C}-\mathrm{H}$ meta disubsitusi benzen.

Pita serapan yang teramati pada $1629,21 \mathrm{~cm}^{-1}$ dan $1664,64 \mathrm{~cm}^{-1}$ menunjukkan gugus fungsi $\mathrm{C}=\mathrm{N}$. Gugus fungsi $\mathrm{C}=\mathrm{O}$ untuk aldehid terlihat pada 766,74; 896,94; $1728,29 \mathrm{~cm}^{-1}$ dan $1739,87 \mathrm{~cm}^{-1}$. Pita serapan pada $1059,93 \mathrm{~cm}^{-1}$ dan $1255,71 \mathrm{~cm}^{-1}$ menunjukkan gugus C-O. 


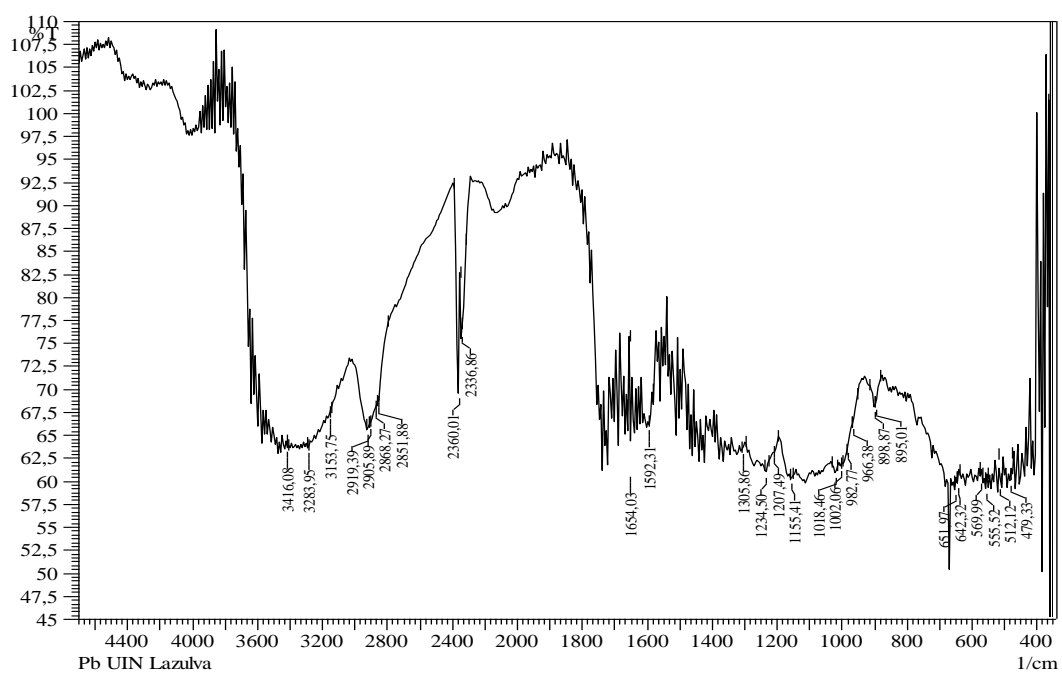

Gambar 2. Spektrum FTIR dari kulit buah pinang sesudah biosorpsi dengan ion logam $\mathbf{P b}^{2+}$

Gambar 2 menunjukkan spektrum FTIR dari kulit buah pinang sesudah biosorpsi dengan ion logam $\mathrm{Pb}^{2+}$, terjadi pergeseran gugus fungsi $\mathrm{N}-\mathrm{H}$ (amina primer) dari $3413,19 \mathrm{~cm}^{-1} \mathrm{ke}$ $3416,08 \mathrm{~cm}^{-1}$ dan gugus $\mathrm{O}-\mathrm{H}$ bergeser dari $3240,55 \mathrm{~cm}^{-1} \mathrm{ke} 3283,95 \mathrm{~cm}^{-1}$. Juga terjadi pergeseran gugus $\mathrm{N}-\mathrm{H} 3064,06 \mathrm{~cm}^{-1}$ menjadi $2919,39 \mathrm{~cm}^{-1}$ dan gugus $\mathrm{C}=\mathrm{O}$ bergeser dari $1151,55 \mathrm{~cm}^{-1}$ ke $1155,41 \mathrm{~cm}^{-1}$. Berdasarkan spektra spektroskopi FTIR dapat disimpulkan bahwa gugus fungsi yang berperan mengikat ion logam $\mathrm{Pb}^{2+}$ dan $\mathrm{Cd}^{2+}$ oleh kulit buah pinang sebagai biosorben adalah gugus fungsi amina $(\mathrm{N}-\mathrm{H})$, alkohol $(\mathrm{O}-\mathrm{H})$ dan karbonil $(\mathrm{C}=\mathrm{O})$.

\section{Pengaruh pH Larutan}

Salah satu faktor yang sangat penting yang mempengaruhi biosorpsi ion logam adalah pH larutan. Parameter ini berhubungan secara langsung dengan kemampuan ion hidrogen bersaing dengan ion logam untuk mendapatkan sisi aktif pada permukaan biosorben (Sari \& Tuzen, 2009). Pengaruh $\mathrm{pH}$ larutan terhadap biosorpsi ion logam $\mathrm{Pb}^{2+}$ oleh kulit buah pinang dalam penelitian ini dilakukan pada rentang $\mathrm{pH} 2$ sampai dengan $\mathrm{pH}$ 6. $\mathrm{pH}$ optimum biosorpsi ion logam $\mathrm{Pb}^{2+}$ ditentukan dengan menghitung \% biosorpsi ion logam $\mathrm{Pb}^{2+}$ sebagai fungsi $\mathrm{pH}$ dan jumlah ion logam yang teradsorpsi (Q) sebagai fungsi $\mathrm{pH}$.

Pengaruh $\mathrm{pH}$ terhadap jumlah ion logam $\mathrm{Pb}^{2+}$ yang teradsorpsi dapat dilihat pada Gambar 3 berikut: 


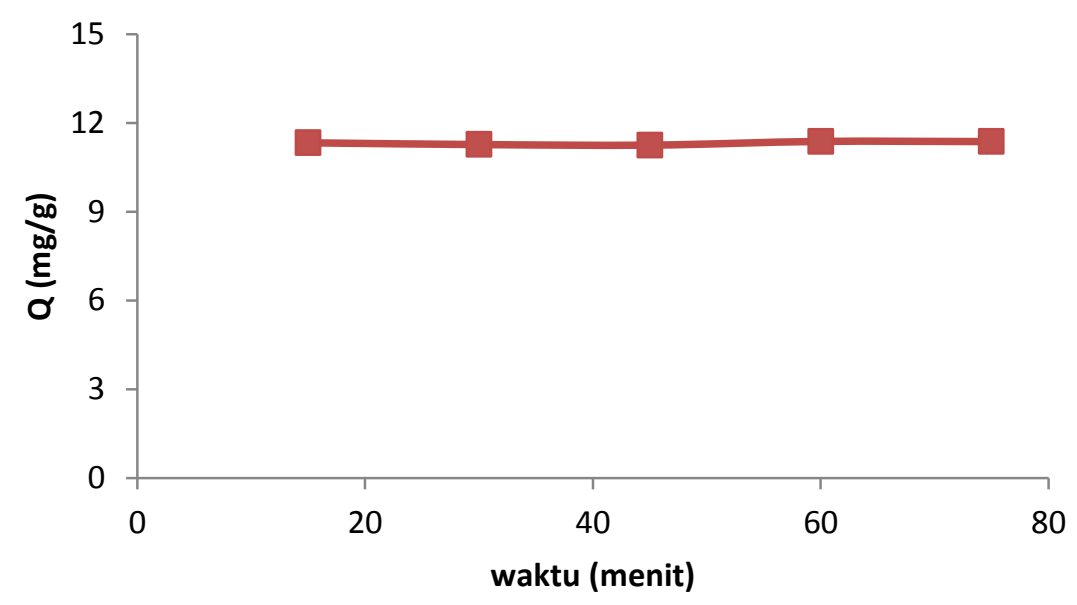

Gambar 3. Pengaruh $\mathrm{pH}$ terhadap jumlah ion logam $\mathrm{Pb}^{2+}$ yang teradsorpsi

Gambar 3 menunjukkan bahwa biosorpsi dari ion $\mathrm{Pb}^{2+}$ meningkat dari 21,90\% menjadi $92,50 \%$ dengan meningkatnya $\mathrm{pH}$ larutan dari $2 \mathrm{ke} 6$. Jumlah ion logam yang terserap dalam $\mathrm{mg} / \mathrm{g}$ sampel kulit buah pinang terjadi peningkatan jumlah ion logam ion logam $\mathrm{Pb}^{2+}$ meningkat dari $1,10 \mathrm{mg} / \mathrm{g}$ menjadi $4,63 \mathrm{mg} / \mathrm{g}$. Jadi $\mathrm{pH}$ larutan memiliki dampak yang signifikan dalam proses penyerapan ion logam $\mathrm{Pb}^{2+}$ menggunakan kulit buah pinang sebagai biosorben. Hal ini disebabkan oleh pengaruh muatan pada permukaan biosorben dan jenis ion logam dalam larutan. Meningkatnya $\mathrm{pH}$ larutan, meningkatkan jumlah ion logam yang diserap. Hal ini dapat dijelaskan berdasarkan fakta bahwa konsentrasi ion $\mathrm{H}_{3} \mathrm{O}^{+}$sangat tinggi pada $\mathrm{pH}$ rendah, sehingga permukaan biosorben secara keseluruhan menjadi bermuatan positif, karena terjadinya protonasi gugus-gugus fungsional seperti amina, amida, dan karbonil. Hal ini mengakibatkan kompetisi antara ion $\mathrm{H}_{3} \mathrm{O}^{+}$dengan ion logam untuk sisi aktif pada permukaan biosorben, sehingga daya serap biosorben kecil pada $\mathrm{pH}$ rendah. Dengan meningkatnya $\mathrm{pH}$ larutan, konsentrasi ion $\mathrm{H}_{3} \mathrm{O}^{+}$dalam larutan semakin berkurang dan mengurangi kompetisi ion logam untuk sisi aktif, sehingga penyerapan biosorben meningkat dengan meningkatnya $\mathrm{pH}$ larutan (Yussof, et al., 2014).

Berdasarkan grafik diatas maka didapatkan $\mathrm{pH}$ optimum biosorpsi ion logam $\mathrm{Pb}^{2+}$ menggunakan kulit buah pinang adalah 6 . Hal ini sesuai oleh penelitian sebelumnya yang dilakukan oleh Putra yang menyatakan bahwa dengan meningkatnya nilai $\mathrm{pH}$ dari 2 menjadi 6 terjadi peningkatan jumlah $\mathrm{Cu}^{2+} \mathrm{Pb}^{2+}$ dan $\mathrm{Zn}^{2+}$ yang diserap menggunakan serbuk batang kelapa, kulit telur dan ampas tebu (Putra, et al., 2014).

\section{Pengaruh Kosentrasi Awal Ion Logam}

Konsentrasi awal ion logam $\mathrm{Pb}^{2+}$ divariasikan dari $10-50 \mathrm{ppm}$ dan jumlah biosorbent yang digunakan dibuat konstan yaitu $0,1 \mathrm{~g}$ dengan waktu kontak 60 menit. Jumlah ion logam yang terserap dalam bentuk $\mathrm{Q}(\mathrm{mg} / \mathrm{g})$ yang ditunjukkan pada Gambar 4 . Dari gambar terlihat terjadi peningkatan jumlah ion $\mathrm{Pb}^{2+}$ yang terserap dari $2,21 \mathrm{mg} / \mathrm{g}$ menjadi $11,63 \mathrm{mg} / \mathrm{g}$ dan ion $\mathrm{Cd}^{2+}$ meningkat dari $1,69 \mathrm{mg} / \mathrm{g}$ menjadi $11,28 \mathrm{mg} / \mathrm{g}$. jadi biosorpsi maksimum terjadi pada konsentrasi awal ion logam $50 \mathrm{ppm}$. 
Secara teori, peningkatan konsentrasi ion logam akan meningkatkan kapasitas penyerapan, karena semakin banyak ion logam yang akan terikat pada gugus fungsi suatu biosorbent. Kapasitas penyerapan akan meningkat dengan meningkatnya konsentrasi ion logam (Zulkarnain, et al., 2015). Menurut Putra, peningkatan jumlah ion logam yang diserap pada konsentrasi tunggi disebabkan oleh dua faktor, yaitu tingginya kemungkinan interaksi antara ion logam pada permukaan biosorbent dan difusi ion logam dengan kecepatan yang tinggi pada permukaan biosorben (Putra, et al., 2014).

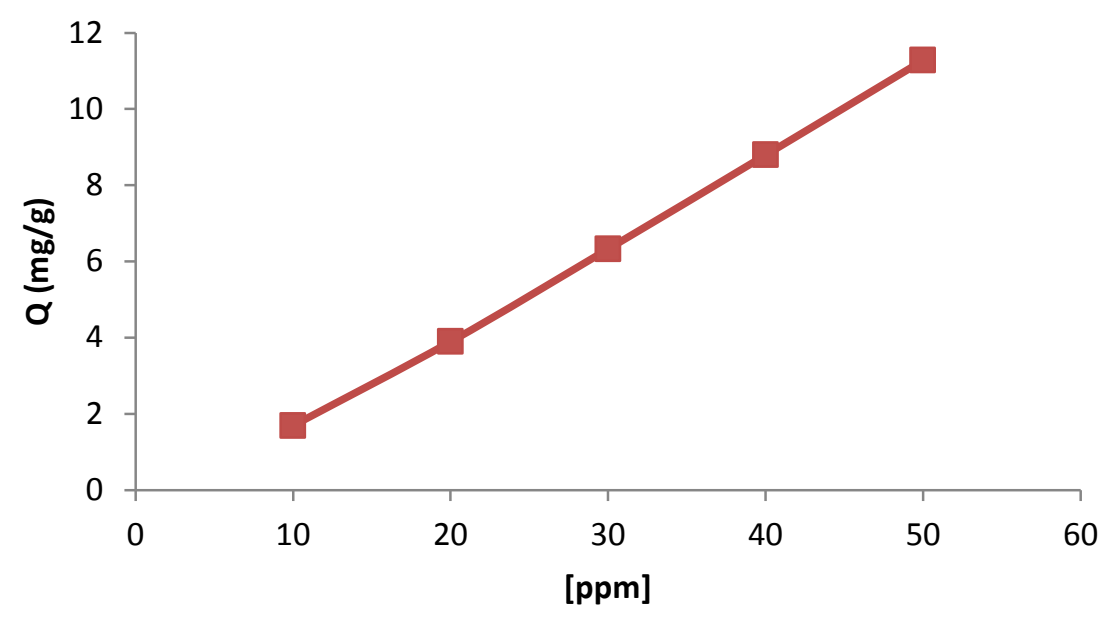

Gambar 4. Jumlah ion logam $\mathrm{Pb}^{2+}$ yang diserap dalam $\mathrm{mg} / \mathrm{g}$ menggunakan kulit buah pinang dengan variasi konsentrasi awal ion logam.

\section{Pengaruh Waktu Kontak}

Proses biosorpsi logam $\mathrm{Pb}^{2+}$ dengan variasi waktu kontak 15 - 75 menit ( rentang waktu 15 menit) dilakukan dengan mengambil kondisi optimum sebelumnya yaitu pH larutan 6 dan konsentrasi awal larutan $50 \mathrm{ppm}$. Jumlah ion logam yang terserap (Q) yang terlihat pada Gambar 5. Dari gambar terlihat bahwa jumlah ion logam $\mathrm{Pb}^{2+}$ yang terserap pada menit ke 15 s.d menit ke 45 mengalami penurunan dari 77,88 mg/g menjadi 52,40 mg/g dan kembali naik pada menit ke 60 yaitu $11,02 \mathrm{mg} / \mathrm{g}$ dan mencapai $11,41 \mathrm{mg} / \mathrm{g}$ pada menit ke 75 . Walaupun kenaikan jumlah ion yang terserap tidak terlalu signifikan dari menit 60 ke menit 75. 


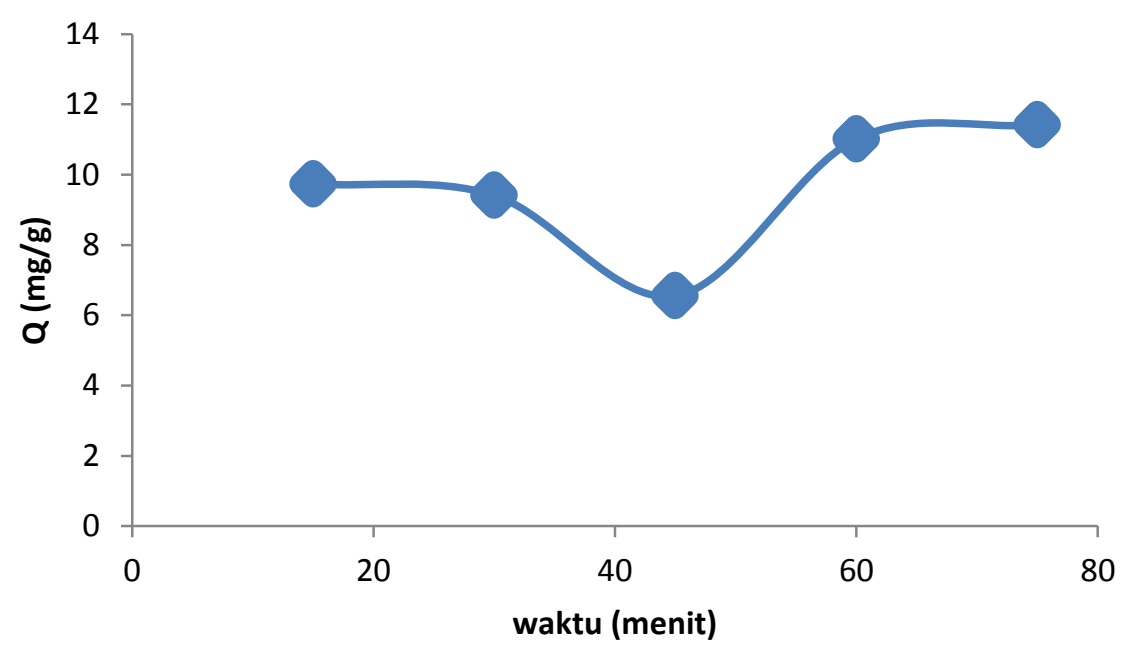

Gambar 5. Jumlah ion logam $\mathrm{Pb}^{2+}$ yang diserap dalam mg/g menggunakan kulit buah pinang dengan variasi waktu kontak.

Secara umum adsorpsi akan mengalami peningkatan seiring dengan bertambahnya waktu kontak dan akan mencapai kondisi kesetimbangan. Setelah kondisi kesetimbangan tercapai maka adsorpsi akan mengalami penurunan. Hal ini disebabkan oleh pengaruh pengadukan sehingga sisi aktif dari biosorben yang telah mengalami ikatan dengan ion logam akan terganggu ikatannya sehingga lepas

\section{Model Isotherm}

Model isotherm adsorpsi telah digunakan untuk menggambarkan interaksi antara ion logam dalam larutan dengan adsorbent. Model isoterm dapat digunakan untuk menjelaskan distribusi dari ion logam dalam fase cair dan padat ketika mencapai kesetimbangan. Model isotherm yang paling sering digunakan adalah Freundlich dan Langmuir, dalam penelitian ini digunakan model isoterm Langmuir.

Model isotherm Langmuir mengasumsikan semua sisi pada permukaan adsorben memiliki energi yang sama. Selama proses adsorpsi, ion logam membentuk monolayer pada permukaan adsorbent dan ketika semua sisi sudah terisi maka tidak akan ada ikatan yang terjadi.

Bentuk linear dari persamaan langmuir adalah

$$
\frac{C_{e}}{q_{e}}=\frac{C_{e}}{q}+\frac{1}{Q_{b}}
$$

dimana $\mathrm{Q}$ adalah adsorpsi maksimum pada monolayer $(\mathrm{mg} / \mathrm{g}), \mathrm{Ce}$ adalah konsentrasi kesetimbangan ion logam (mg/L), qe adalah jumlah ion logam yang diadsorpsi per unit berat adsorbent pada konsentrasi kesetimbangan $(\mathrm{mg} / \mathrm{g})$ dan $\mathrm{b}$ adalah konstanta Langmuir yang berhubungan dengan sisi ikatan $(\mathrm{mL} / \mathrm{mg})$ dan digunakan untuk mengukur energi adsorpsi. $\mathrm{Q}$ dan b dapat ditentukan dari plot linear $\mathrm{C}_{\mathrm{e}} / \mathrm{q}$ dan $\mathrm{C}_{\mathrm{e}}$. 
Gambar 7 berturut-turut menunjukkan grafik plot $\mathrm{Ce} / \mathrm{qe}$ versus $\mathrm{Ce}$ dari logam $\mathrm{Pb}$, dengan harga $\mathrm{R}^{2}$ untuk logam $\mathrm{Pb}$ 0,8934. Dari plot tersebut diperoleh harga $\mathrm{Q}$ (penyerapan maksimum) adalah $0,877 \mathrm{mg} / \mathrm{g}$ untuk logam $\mathrm{Pb}$.

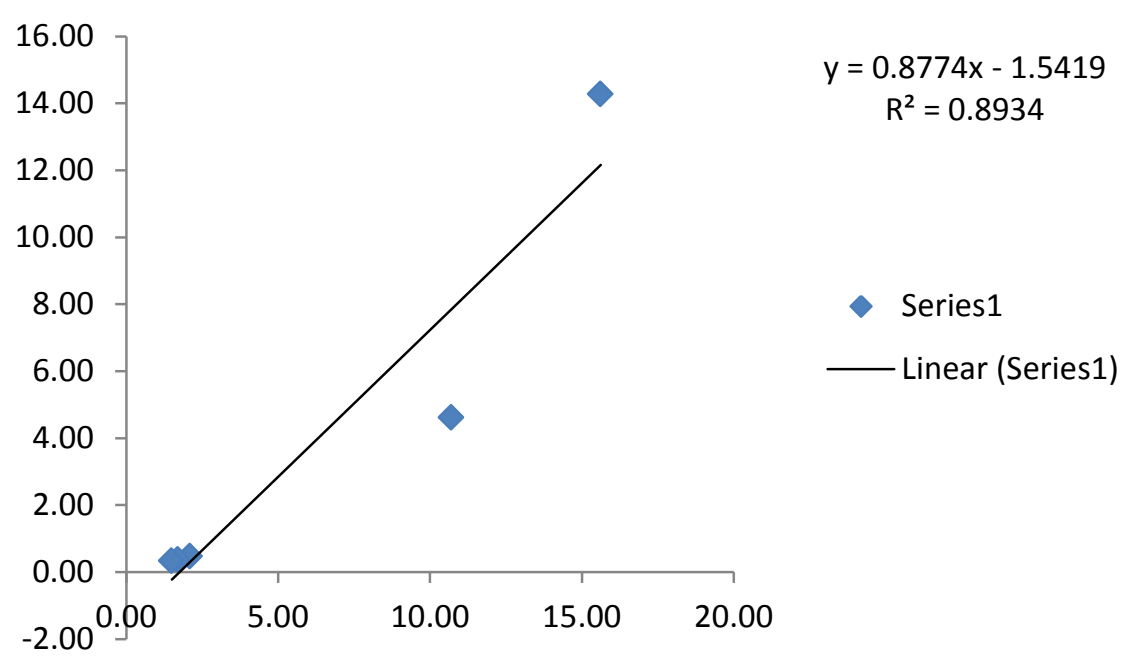

Gambar 6. Adsorpsi Isotherm Langmuir logam $\mathrm{Pb}$ menggunakan kulit buah pinang

\section{PENUTUP}

\section{Kesimpulan}

Kulit buah pinang yang jumlah berlimpah dan kurang dimanfaatkan bisa dijadikan sebagai material biosorpsi untuk menghilangkan ion Logam $\mathrm{Pb}$ (II) dari larutan. Hasil pengukuran kadar ion Logam $\mathrm{Pb}(\mathrm{II})$ menggunakan Spektrofotometer serapam Atom dengan variasi $\mathrm{pH}$ dan konsentrasi ion logam menunjukkan bahwa $\mathrm{pH}$ optimum biosorpi adalah 6 dan waktu kontak optimum untuk logam $\mathrm{Pb}$ (II) adalah 75. Sedangkan konsentrasi optimum biosorpsi terjadi pada konsentrasi $50 \mathrm{ppm}$. Berdasarkan spektra spektroskopi FTIR dapat disimpulkan bahwa gugus fungsi yang berperan mengikat ion logam $\mathrm{Pb}^{2+}$ oleh kulit buah pinang sebagai biosorben adalah gugus fungsi amina $(\mathrm{N}-\mathrm{H})$, alkohol $(\mathrm{O}-\mathrm{H})$ dan karbonil $(\mathrm{C}=\mathrm{O})$. Hasil isotherm Langmuir diperoleh harga $\mathrm{Q}$ (penyerapan maksimum) untuk logam $\mathrm{Pb}$ (II) adalah $0,877 \mathrm{mg} / \mathrm{g}$.

\section{DAFTAR PUSTAKA}

Khoiriah, Furqoni, F., Zein, R., \& Munaf, E. (2015). Biosorption of Pb(II) and Zn(II) from aqueous solution using langsat (Lansium domesticum Corr) fruit peel, Journal of Chemical and Pharmaceutical Research, 6(3), 86-97.

Kurniasari, I. L. Riwayati, Suwardiyono. (2012). Pektin sebagai alternatif bahan baku biosorben logam berat, Momentum, 8(1), 1-5. 
Mawardi, Munaf, E., Kosela, S. \& Wibowo, W. (2014). Pemisahan ion Krom (III) dan Krom (IV) dalam larutan dengan menggunakan biomassa alga hijau spyrogyra subsalsa sebagai biosorben. Reaktor, 15(1), 27-36.

Sari, A. \& Tuzen, M. (2009), Kinetic and equilibrium studies of biosorption of $\mathrm{Pb}(\mathrm{II})$ and $\mathrm{Cd}(\mathrm{II})$ from aqueous solution by macrofungus biomass, Journal of Hazardous Materials, 164(2-3), 1004-1011.

Yusoff, S.N.M., Kamari, A., Putra, W.A., Ishak, C.F., Mohamed, A., Hashim, N,... Isa, I.M. (2014). Removal of $\mathrm{Cu}$ (II), $\mathrm{Pb}$ (II) and $\mathrm{Zn}$ (II) ions from aquous solutions using selected agricultural wasres: adsorption and characterisation studies. Journal of Environmental Protection. 5(4), 289-300.

Putra, W. P., Kamari, Azlan, Yusoff \& Siti N. M. (2014). Biosorption of Cu(II), Pb(II), and $\mathrm{Zn}$ (II) ions from aqueous solutions using selected waste materials: adsorption and characterisation studies, Journal of Encapsulation and Adsorption Science, 4(1), 25 23.

Zulkarnain, C., Sari, P. N., Zein, R. \& Munaf, E. (2015), Calcium alginate immobilized sugar palm fruit (Arenga pinnata Merr) shell for removal $\mathrm{Pb}$ (II) and $\mathrm{Cd}(\mathrm{II})$ ions, Journal of Chemical and Pharmaceutical Research, 7(5), 965-972. 